\title{
Marie Corelli's The Secret Power in Bengali Rendering: Translation, Indianisation and Cultural Criss-crossing
}

\author{
Pritha Kundu \\ Independent researcher, West Bengal, India
}

\begin{abstract}
Since the 1980s and 1980s, a new trend in the discipline of Translation Studies has emerged beyond the boundaries of Europe. Scholars from post-colonial nations like Canada, India, China, Africa, and Latin America have argued that translation was used in the past as a means of depriving the colonised people of their voice. In the colonial structure, the hegemonic culture used to dominate, making the others subservient. Translation in the colonial period reflected that hierarchy. In this light, decades after the independence of India, translation from a reverse direction, that is, rendering popular English texts in minority languages, may be seen as a process of "writing back". Even if the original text concerned is not a "political" writing, and the translation is apparently meant for "safer-zones" such as "young students' literature", a tendency of claiming cultural equality, overlapping the translator's own cultural and literary heritage with the original author's, can be discovered. This paper attempts to focus on these issues in a particular text - the 1995 Bengali translation of Marie Corelli's 1921 science-fiction, The Secret Power. The purpose of this paper is to explore how Sudhindranath Raha has intermingled Biblical references and Western contexts with allusions to Indian culture and Sanskrit literature, thereby claiming a space for mutual understanding and respect between two cultures.
\end{abstract}

Keywords: translation, The Secret Power, cultural criss-crossing

\section{Introduction}

Translation in a post-colonial context has now been viewed as a version of "writing back", a process of claiming a dialogic interaction between the master or original culture and its language, and the once-dominated culture which has now become "free". In case of critical and canonical texts, the process is often conscious, whereas translating a "safe" text-some popular fiction, fantasy or children's text may not be consciously so. However, the process can be seen at work, at least in a subtle and semiconscious way. For the discussion of this phenomenon, this paper has chosen a science-fiction or fantasy-novel by Marie Corelli, a popular, best-selling British author who was active throughout the late 19th and early 20th century.

\section{Marie Corelli in Bengali Translation}

A number of Marie Corelli's novels have been translated into several Indian languages including Bengali. Bengali translations of Corelli, in general, show considerable variety of approach and tone. Bhuban Candra

Pritha Kundu, independent researcher, West Bengal, India. 
Mukhopādhyāy, in his enthusiasm to expose the material and spiritual corruption within the society of the British "masters" translated The Sorrows of the Satan (1895), from the point of view of a well informed "subject", representing the colonial Bengal. Kumāreś Ghoșe, on the other hand, criticized the post-colonial trend of continuing to imitate British culture and admonished his intend readership that if Indian women are to imitate Western women, they should follow an "Angel in the House" like "Thelma”. Mukhopādhyāy's translation of The Sorrows of the Satan came in 1903, and Ghoșe's translation of Thelma was published in the 1960s. The ideological intensions of these translations are not difficult to understand, given the colonial and post-colonial contents of their publications. The Bengali translation of Corelli's post-World War-I novel, The Secret Power (1921), however, comes much latter, and avoids the pressure of the Anglo-Oriental tension between the "Self" and the "Other". Significantly, The Secret Power itself is more cosmopolitan in nature than the other Corelli-novels. It is preoccupied with the post-war anxiety for the future of the human race in general, not any nation in particular. Rāhā elaborates the anti-war pronouncements in Coerlli's novel. Corelli wrote, with the experience of the First World War fresh in her mind, whereas Rāhā's treatment of the anti-war section clearly shows a man writing with a post-World War-II sensibility, for a younger generation. Unlike Mukhopādhyāy’s or Ghoșe’s work, his translation was meant for children, with an appreciative stamp from the educational board of the government of West Bengal.

\section{Translating for Children: Tempering the Erotico-Psychological}

The translation shows Rāhā's capability of compression, which deserves critical attention. In compressing, however, he omits those portions in the original, which attempt to render, psycho-analytically, Roger Seaton's love-and-hate relationship with Morgana and Manella. The account of Seaton's relationship with Morgana, in New York society, is just summed up by Rāhā. He seems to avoid the psychological and erotic complexities, considering them unsuitable for the school-students. These omissions and compressions lessen the use of flashback technique which is essential to the plot-construction of the original.

Corelli, however, "progressive" in her view of "the woman of the future" like Morgana or Diana (in The Young Diana, 1918), cannot help adhering to the male discourse of stereotyping female vanity of sex-jealousy. In The Secret Power, when Morgana hears Manella speak of her "man in the mountain", she gives a quaint smile and tells her playfully_ _you are an odd girl, but you are quite beautiful... Tell the man on the mountain that I said so" (Corelli, 1921, p. 30) ${ }^{1}$.

In Corelli, Morgana does not tell Manella that she has already gone to visit Seaton. When Manella learns it from Seaton, she is hurt. But in the translation, Morgana tells Manella all about Seaton, and requests her to take care of him, sensing that she is devoted to Seaton. The translation puts in Morgana's mouth such words as:

ye kono din, ye kono muhūrte o mārā poṛte pāre, āgun niye khælā korche o, nijei puṛe morbe se āgune"-ei kathāi spașta bhāșāy boleche Margānā. nā Margānā ār gopan kareni kichui. Maenelāke sab khule boleche. (Rāhā, 1995, p. 25)

[Paraphrase: He will die any day, at any moment. He is playing with fire, and he will be consumed by that very fire" - this is what Morgana has said clearly. No, she has not concealed anything, she has been open to Manella] $]^{2}$.

The way Rāhā changes Corelli's account of the first encounter between Morgana and Manella, seems to be

\footnotetext{
${ }^{1}$ Marie Corelli, The Secret Power, (Methuen, London, 1921), 30. The version used here is the e-book downloaded from http://www.gutenberg.org/files/3831/3831-h/3831-h.htm.

2 Paraphrase from Sudhīndranāth Rāhā (trans.), The Secret Power in Bengali, (Kolkata, Deb Sāhitya Kuțīr, Rpt. 1995) 25. All paraphrases from the Bengali version to English again, are mine.
} 
an attempt to Indianize the situation, without changing the Western names. The very idea of sisterly-bonding, overcoming the initial and instinctive jealousy, by virtue of the noble nature of two women, is an idealistic Indian-Bengali concept—-from the popular Bengali versions of The Mahābhārata portraying Droupadī and Subhadrā (both are wives to Arjuna), to Āshāpurṇā Devī’s family-novel showing "Bakul" and "Arundār Bou" (the wife of Bakul's cousin Arun, whom she loved) in Bakul-kathā, there is a tradition of showing two women characters somehow forming a "sisterly" bond, despite their clashing interests in love or right. Rāhā's "Indianization" of the Manella-Morgana bond, at times, aims at original activity. Susan Bassnett-McGuire, in Translation Studies, relates the translator's creative originality to the Platonic notion in divine inspiration:

The Platonic doctrine of the divine inspiration of poetry clearly had repercussions for the translator, in that it was deemed possible for the "spirit" or "tone" of the original to be recreated in another cultural context. The translator, therefore, is seeking to bring about a "transmigration" of the original text, which he approaches on both a technical and metaphysical level, as a skilled equal with duties and responsibilities both to the original author and the audience. (Bassnett-McGuire, 2002, p. 62)

In Rāhā's translation, the characters of both Morgana and Manella seem to be simplified, which, in turn, become all the more thought-provoking for the reader who has read the original text. For instance, one may cite a section from the translation, where Manella hears Seaton recalling his embarrassment in Morgana's high society (in which he felt like "fish out of water"), and she retorts, almost "recommending" Morgana's character:

d̦āyāy yini tulechilen, tār kāche theke geleo manda thākte nā tumi. Sonāli culer uni lok khārāp nan, katakșan ār ālāp hoyechila, tār-i modhye āmāke āpan kore phelechilen. (Rāhā, 1995, p. 49)

[Paraphrase: It would not have been bad for you if you remained with her who took you out of water. That lady with golden hair is not a bad person. We had a very brief encounter, but how she had taken me into her intimacy].

This is not there in Corelli's text. But, this forces the reader back to a re-reading of the original, with a new interest, in order to explore whether, or to what extent, Corelli's Morgana is capable of taking anybody into confidence and intimacy (āpan kore naeoyā) at all. She has almost loved Roger Seaton, and now, being "deserted" by him she seeks to continue an intellectual war with him, and seems to pity the intellectually inferior woman who loves him now. She can not be intimate with Rivardi who loves and adores her. It is only with father Aloysius, that she can share some feelings and problems, in spiritual terms. But this "intimacy", too, has not come easily. At first, she viewed Aloysius simply as a good and wise priest.

The change of Morgana's attitude towards Don Aloysius, is rendered by Corelli by means of subtle gestures of reverence coupled with love and desire, when Morgana comes to visit him, after her adventure. Rāhā's translation carefully avoids the love-interest by showing their feelings to each other as spiritual, much like that between a philosopher-teacher and a disciple according to the Hindu-Indian culture. In Corelli, the process of establishing the mystic relationship between Aloysius and the inhabitants of the "Golden City", is one of the gradual unveiling - yet not very sure. In Raha's translation, the process is direct, swift, and climactic. In his treatment Morgana does not have a vision of the angelic inhabitant of the "Golden City" through the light-ray. The voice, rather, tells her, to her utter astonishment: “... tomrā yāke fādār aelosiās bole jāna, āmār ākriti thik tẫr-i mato" [I look exactly like the person you know as Father Aloysius] (Rāhā, 1995, p. 81). This single sentence, which is nowhere in the original, immediately creates an epiphanic charm, which is different from the effect of 
the half-certain, half-sustained mystery of the original. This is where the translator becomes an interpreter: he interprets Don Aloysius in a new light. Here translation tends to be a certain kind of intensive reading of the original text, which, finally becomes an "interpretative translation", as John Hollander discusses in his article Visions, Interpretations and Performances. A close reading of the text thus leads to an intra-lingual translation/interpretation from graphic sign to mind.

\section{Attitude Towards Humanity}

Corelli seems to share with her contemporary British writers the post-war concept of the "broken man". Men go to war, engage themselves in destruction, and if they survive, they return with a physical or mental or moral handicap. Corelli also implies that the hope of humanity, if any, lies with creative woman. But she does not seem to be able to make up her mind in determining the "positive" nature of women as something certain. Morgana, at first reflects on the nature of Manella, with a sort of pitiful contempt:

[addressing Seaton] She is just the kind of thing you want to fetch wood, draw water, cook food, bear children... You will be living the baboon-life and your brain will grow thicker and harder as you grow older... (Corelli, 1921, p. 30)

Seaton's downfall, however, is caused not by Manella's primitive influence, but by his own "hubris". Manella, instead, towards the end of the novel, becomes the embodiment of a faint hope for humanity (if any), exercised through her self-sacrificing wife-and-motherhood - to nurse the "broken man" back to life. At the end, Corelli makes Morgana recognize the positive aspect in Manella - "She will surround him with the constant influence of a perfectly devoted love. Dare we say there shall be no healing power in such an influence?" (Corelli, 1921, p. 183).

\section{Changes in Character-Depiction}

The reader, like the changed Morgana, can hope for the best, but the question remains - whether Manella ultimately emerges as an eugenic woman capable of mothering a better race, or whether she represents regression into a primitive and innocent state - the only consolation for a world under constant threat of nuclear war and existential crisis. Rāhā's Bengali translation ignores these evolutionary issues and softens the tension between Morgana and Manella by drawing them into a bond of mutual understanding.

Marie Corelli's attempt to idealize Morgana is also ambiguous. She is talented, inventive, and courageous. But her power and resourcefulness come largely from her enormous wealth. In the first five chapters, she appears to be flirtatious, the rich friends in New York talk of her as a woman of strange whims. Rāhā makes her a "feminist" champion of her sex, carefully translating her tribute to Madame Curie, and her retorts at male gallantry. But in Corelli, she is not a "feminist" answer to patriarchy in a broader sense, for she has little regard for other women of "inferior" intellect, be it Manella, Mrs. Boyd or Lady Kingswood. At times, she shows utter indifference to humanity or human feelings, which suits her temper as a "fey"-woman. "There is no such thing as love", she says and the translator, in his role as an interpretator promptly brings in the comparison—-e ki sittaner kathār pratidhvani?" [“Is it an echo of Seaton's voice?”] (Rāhā, 1995, p. 37). Again, her view of human beings as "microbes" and her words, resemble Seaton's - "I shall not aid the continuation of the race... It is too stupid and too miserable to merit continuance" (Rāhā, 1995, p. 37). Morgana too has a destructive power which is sublimated into a creative force comes out when she is angry with Rivardi and Gaspard - "You refused to obey 
me!... Then... I destroy this airship and ourselves in less than two minutes!” (Corelli, 1921, p. 162)

In Corelli, it is the influence of Don Aloysius that ultimately guides Morgana's "positive" potential. But her "White Eagle" cannot last for the sake of future humanity. It rescues Manella and Seaton— the only act by which it proves its positive power. Corelli intends her readers to believe that Morgana finally succeeds in her spiritual quest. But before she can enter the "Golden City", her scientific achievement crashes in the desert and ceases to be a symbol of "science as a bliss". Given Morgana's declaration of the "White Eagle" as her "baby", one may also interpret its destruction as a failure of her "mothering" capability. She can attain "true happiness" for herself, but she is incapable of bearing a greater responsibility for the suffering humanity. Rāhā's translation gives an interesting twist to this problem at the ending. He does not show the airship destroyed; it simply disappears. And he emphasizes the role of the wise Don Aloysius and the questioning Rivardi, who continue to live and struggle for humanity:

“āmār āhvān āste deri āche bodh hay--” bollen ælosiās-- "āmār kāj śeș hayni”--

Aelosiyās mājhe mājhe tār (Margānā) kathā śunte pācchen śabdaraśmite. "se soubhāgya āmār-o kæno habenā fādār?" Ribhārdi nitya kākuti kare ælosiyāser kācche. (Rāhā, 1995, p. 91)

["Perhaps my call is yet to come--" said Aloysius-- "my work is not finished--" Aloysius hears her voice through sound-ray, at times. "Why may I not have that pleasure, Father?"-- Rivardi pleads to him everyday].

Thus one may see how the translator endows the "minor" or supporting characters with a new dimension at the end.

Now one may turn to Roger Seaton, an equally complex character like Morgana, and further problematized by the translator's approach. Robyn Hallim's unpublished thesis, Marie Corelli: Science, Society and the Best-Seller tells us that Seaton is a "Faustus"-figure "who has opportunities to choose between good and evil" (Hallim, 2002, p. 234). Hallim's view here seems partially correct: of course, Seaton shares some traits with Faustus but he does not actually choose between good and evil; rather he is wrong in his notion of "good". He is a misguided idealist who justifiably detests the evil of war, but his way of annihilating "evil" leads him to further destruction. He seems to be a follower of the Old Testament-God, ever-ready to punish the wrongdoers; and Corelli does not seem to condemn him altogether. There are several instances where she portrays Seaton in an admirable light. Here one may cite two of them. The first "positive" picture of Seaton comes, when he, after working for six or seven hours at a stretch, takes a short nap-

His face in repose was a remarkably handsome one - a little hard in the outline, but strong, nobly featured an expressive of power - an ambitious sculptor would have rejoiced in him as a model for Achilles... (Corelli, 1921, p. 69)

The second instance is even more striking. Seaton lashes out at the mean notions of commercial profit lurking behind any great war; he warns the war-mongering bourgeoisie with an air of sermonizing like a Judaic prophet-

...let them take heed how they touch money coined in human blood. I-one man only-but an instrument of the Supreme Intelligence - - I say and swear there shall be no more wars! (Corelli, 1921, p. 83)

Seaton utters these words with an attitude that inspires awe in the listener, and Mr. Gwent, looking at him recalls the fifth verse in the Third Psalm: 
I laid me down and slept; I awaked for the Lord sustained me. I will not be afraid of ten thousands of people that had set themselves against me round about. (The Book of Psalms, 3:5-6).

It is difficult to be sure whether Corelli inserts the Psalm to describe a "negative" force with deliberate irony, or whether she does it to show, seriously, how an "old" faith itself turns obsolete, and wrong, in a new world. Sam Gwent's argument with Seaton, at one point, sounds like a parody of Abraham's bargain with God on the issue of destroying Sodom and Gomorah:

Wilt thou also destroy the righteous with the wicked?

Peradventure there be fifty righteous within... (Genesis, 18:23-24).

The irony is that God can spare if He wills, but a man cannot, even if he claims divine authority behind his work. Rāhā has not translated this section line by line, but he is certainly aware of the problem as he shows in his own way.

This may become clear by making a comparison between what Corelli's Seaton says and what Rāhā makes out of it. Corelli's Seaton, as we have seen swears in front of Gwent that "there shall be no more wars". In Rāhā's translation, Seaton does not swear in front of any human being. But the importance of swearing an oath, in the name of the "Supreme Intelligence" is conveyed much earlier in the translation, not through the voice of an enraged Seaton, but through the narratorial comment, which lends to an extra edge of gravity and sensibility. The translator also elaborates Seaton's personal experience of war (which is merely hinted at by Marie Corelli), so that his motive behind his research becomes all the more appealing:

Rakter nadī boiche māthe prāntare upatyakāy, mājhe mājhe gādā hoye pod̦e āche hatāhata mānușer deha, tībra tīkșna ārtanād uțhche dhõyāțe ākāś bidīrṇa kore, esab tār pratyakșa abhijñatār jinis... se-anubhūtir jvālā aekhano tāke unmād kore tole... sedine bhagabān sākșī kore ye pratijñā se niyechila, bholeni tār kathāo. Sei pratijñā pūran̦er janyai tār ei jugabyāpī bijñān sādhanā. śaktimade matta ei ye jātiguli pṛthibīr, eder śaktir ahạkār se cūrṇa korbe. (Rāhā, 1995, p. 11)

[Rivers of blood are flowing across the fields and valleys, bodies - dead and injured are heaped at places, a shrill cry of pain is about to rend the sky, all these are his direct experience. The trauma of that feeling maddens him still... he has not forgotten the oath he took in the name of God. This epochal science-asceticism (bijñān sādhanā) of his is meant to keep that very oath. These power-mongering races of this earth, he will crash their pride].

This vivid picture is deliberately added by the translator - artist, and this reflects his sympathy for Seaton as a tragic character. He, a single man claims divine approval in the manner of an Old Testament prophet, without realising that civilization has come a long way from the time when one godlike hero could be the master and guide to all other worldly creatures.

Seaton is cynical, proud and misogynistic - this is clear from both Corelli's text and the translation. Corelli, however, does not fail to describe Seaton's "tender" aspects too. He calls Manella "dear" ("lakșitt") in translation, with an added sense of affection and sympathy in colloquial Bengali) and "child" (ætatukun bāccā - in translation). In Corelli, he caresses and kisses her three times, as a brother or father might have done to her (Corelli, 1921, pp. 6, 71, 118). The translation, in his work meant for school-students, cannot possibly reproduce these actions of physical intimacy, just as he omits that section where Seaton grabs Morgana's arms and pulls her up, from a half-lying posture in front of his cottage (Corelli, 1921, p. 11). Such omissions reduce the possibility of looking into the character of Seaton, apparently cold and rough, but occasionally capable of 
expressing his inner passion - through physical force physical caress. The translator is aware of this problem, and so he tries to convey Seaton's inner dilemma in terms of thoughts, as he thinks of Morgana- "se to icche korlei margānā rayāler pāṇigrahaṇ-i korte pāre" [Seaton could have married Morgana Royal if he wished]. Again Rāhā makes him feel for Manella:

Meyețār janya duḥkha hay Sītaner. kașta āche barāte or. kintu Sītan tār kī korte pāre? Kichui nā!... karār jinis thākte pārto ækțāi śudhu nijer sādhanā bisarjan diye gerasta-jībaner nonirāmite d̦ūbe jāoyā. (Rāhā, 1995, p. 12)

[Seaton feels sorry for the girl. She is fated to be miserable. But what can Seaton do for that? Nothing at all! Only one thing was to do, to renounce his own ascetic experiment and get doomed to a petty domestic life].

\section{From Mad Scientist to “Arrogant Hermit”: Remoulding the Hero's Character}

Again and again, to emphasise Seaton's devotion to his work, Rāhā uses such terms as "tapasyā" and "sādhanā" which, to any Indian reader, would suggest a hermit-like nature (Interestingly, in Hindu mythology, powerful hermits are often excessively arrogant). The idea reaches its climax, when Manella stealthily proceeds to Seaton's hut, so that he cannot be conscious of her presence: "dekhlei to Sịtan kukur-tārāā korbe tāke- 'dūr ha sarbanāśî! āmār tapobhnga korte esechis! dūr ha. tā naile ekșuṇi bhasma kore felbo'”(Rāhā, 1995, p. 48) [As soon as seeing her, Seaton will chase her away like a dog- “... Get away, wench! What, you have come to spoil my meditation! Go away, or I will reduce you to ashes]. Such words as "tapobhanga" and "bhasma" immediately elevate Seaton to a semi-divine level. Moreover, it is very likely that at this point, any Indian reader would recall the myth of the burning of "Madana" (god of Eros in Indian mythology), by the enraged Lord Siva, a divine meditation-practitioner and one of the Supreme Trinity in the Hindu pantheon. This section is a unique conception on the part of the translator. No western writer could have naturally conceived of such a suggestive expression.

\section{Indianisation Through Cultural Allusions}

There are other instances when Sudhīndranāth wittingly or unwittingly, engages himself in a process of cultural transaction. Corelli has tried to give an impression of heroic illusion, inviting comparison between Seaton and Achilles or some Old Testament-hero. Rāhā's allusion to Siva, then appears to be an attempt to create an Indian equivalent to that. Interestingly again, Rāhā's translation of that section where Morgana goes to meet Seaton under the romantic moon, is full of echoes from Kālidāsa's Kumārasambhavam:

candran gatā padmaguñān na bhuykte

padmāśritā cāndramasīmabhikhyām.

umāmukhantu pratipadya lolā

dvisamiśrayāmi prītimavāpa Lakṣmīḥ. (Kālidāsa, 1978, p. 1/43)

[The goddess Laksmī could not dwell in both the moon and the lotus. Now, by dwelling in Umā's face, she enjoys both her abodes at the same time $]^{3}$.

antaścarān̄ām marutām nirodhān-

nivāta-nișkampamiva pradīpam. (Kālidāsa, 1978, p. 3/48)

[The air was internalized, and the figure was like an unflickering flame, affected by no air].

\footnotetext{
3 All paraphrases from the Sanskrit text, here and afterwards, are mine.
} 
Now we may turn to Rāhā's translation, which describes Morgana's charms, in terms clearly reminiscent of certain phrases used in the ślokas quoted above.

śubhra jyotsnāy snāta suśubhra mūrtikhāni,... Bātāsțā pore giyeche hațāt. mūrtițir anger basane kã̃puni nei bindumātra. (Rāhā, 1995, p. 13)

[the figure bathed in the white moonlight... suddenly the wind has been still. The attire on the body of the figure is not flowing a bit].

This is an elaborate sense-echo of Kālidāsa's "nirodhānnivāta-nișkampa" (and Rāhā describes Morgana elsewhere as "pāvakaśikhā” cf "pradīpam”). And the later part of the description “... thik jæna ardhavikaśita maegnoliā kusumer gāye pāprị upar pāprị... paripūrṇa jyochanāy phuțe utheche æk khānā sundar mukh" [Just like a half-blossomed magnolia, one petal on another,... a beautiful face blooming in full moonshine] echoes Kālidāsa's comparison between Umā's beautiful face and the beauty shared by the moon and the lotus. "Lotus" is replaced by "Magnolia".

Thus Morgana's approach to Seaton, set against the romantic background of the Californian hill-scape may be compared to the divine "romance" between Umā and Lord Siva, set against the backdrop of the Himalayas. The comparision may seem odd, but its charm is not to be missed. The romantic scene, both in Corelli's text and Rāhā's translation is disrupted when Seaton and Morgana begin to speak to each other, with mockery. But the moment created by the translator's allusion to Kālidāsa's text, is sure to enchant the Indian readers. Again, Rāhā's use of the words like "girisānu" (Mountain-foot), "meghamālā" (cloud-garland), to describe the cloud floating above the Mount Siera Madre, remind us of the classic beauty of the Meghadütam (The Clould-messenger). The language of expressing beauty and sublimity certainly differs from Sanskrit to English, but Rāhā's Bengali translation, as a means of cultural transaction, descends beneath the exterior disparities of two languages in order to bring into vital play their analogous, and at the final depths, common principles of being-as one may say, using George Steiner's idea from After Babel.

Rāhā's allusion to Śiva and Umā operates not only in terms of the rhetoric of the Indian classics. If we turn from the classical-mythological Sanskrit texts to the folk-tradition of Bengal, we can see that Umā is a rich man's much-beloved, single daughter, and Śiva, an uncouth, poor person living in creamation-spots and deserted places (śmaśāna-maśāna) outside the "civil" society. This is fairly in keeping with the socio-cultural barrier between Morgana and Seaton. Raha's treatment of the rumour about the marriage of Morgana and Seaton, using such sentences as_- “dhanakuber duhitā Margānā Rayāl nāki baramālya dite coleche oi dāđioyālā bhālukțāke” (Rāhā, 1995, p. 63) [That rich man's daughter, Morgana Royal — as the rumour went — was going to garland that beardy bear] provides the Bengali readers with an enjoyable picture of folk-gossip, regarding such possibilities of an "odd" marriage.

\section{The Representation of War: Perspectives Changed in Time and Context}

Finally we are to discuss the major change which comes from the translator's anti-war perspective, corresponding to the forces of history and politics of his time. Corelli's critique of war comes along with her personal antipathy to the activities of the press. Adding journalistic spice to the causes of political rivalry among nations, the press, in the first decade of the 19th century, played a vicious role behind World War I.

During the inter-war years, political diplomacy and the rise of nuclear power grew to become a threat to 
humanity, and Corelli's idealist Seaton took it as his duty to oppose them, all alone, with a passionate obstinacy, whereas Rāhā's Seaton shows consideration and calculation, as he seeks to proceed with his discovery. He insists on having permission of the government, to demonstrate the power of his radio-active weapon, somewhere in the desert of Sahara - this appears to be a clear allusion to the first nuclear test conducted by America on July16, 1945 in the desert of North Almogordo, new Mexico. Rāhā's translation of the anti-war pronouncements of Seaton are expressly directed to Nazi aggression and Fascism - which had not been so prominent in Corelli's time, as they became before and during the World War II. Raha's Seaton is deliberately anti-Fascist:

Durbhāgyakrame sabhya jagate æman ækțā jāti māthā tule dãđđieche, yāder balā yete pāre svabhābatahi yuddhabāj... sahābasthāne tārā biśvāsī nay. Kāraṇ anya kāukei tārā jñānbuddhi bā sabhyatār samiskritite nijeder samakakșa mane kare nā. (Rāhā, 1995, p. 56)

[Unfortunately such a race has reared its head in the civilized world, as can be called war-thirsty by nature... they don't believe in co-existence, for they don't consider the others as equal to themselves, in intellect or in culture].

Corelli's Seaton speaks of Germany casually, to use it as an example. Rāhā's Seaton clearly mentions his distrust of the "opportunistic" Germany, which comes from a bitter experience of the World War II, as one may easily recognize from his words- "kon sandhike pabitra mane kare garmani? parājita hole takhan se sandhi kare" (Rāhā 53) [Does Germany consider any treaty with honour? It signs treaties only when it is defeated].

Again Seaton's description of the function and destructive power of his weapon bears an almost uncanny resemblance to the way Hiroshima and Nagasaki were destroyed:

...ǽk khāni chotta plane meghaloker upar diye ure jābe kakhan, tomrā țer-o pābenā. țer pābe, yakhan sei chotta plen theke poṛbe ækțā choțta sarupānā cong tomāder deśer māthāy. kimbā... țer pābār āgei tomāder deś puṛe chāi habe, gũd̦iye ren̦u reṇu hoye jābe, taliye jābe atal samudre. (Rāhā, 1995, p. 57)

[A small plane will pass through the clouds, and you won't even realize — until a thin little cylinder will fall from it on the head of your nation. Or... even before realization, your country will be burnt to ashes, crushed to particles and dissolved into the sea unfathomable].

In fact, on August 6, 1945, at 8 a.m. two American planes were seen above Hiroshima. But the citizens did not care, because they look them for simple "observers". And when the atomic bomb was thrown at the "head of Hiroshima”, as Louis Sneider reported:

Suddenly a piercing, blinding light... burst over the city... Then an earth-shaking shock thundered violently down over the centre of the city, crumbling everything into its range to rubble and dust,... (as cited in Mukhopādhyāy, 1978, Vol. III, p. 1195)

The language used by Rāhā's Seaton is not much different from this. If Marie Corelli had been pre-occupied with the destruction of the World War I, it is also evident how Rāhā was obsessed with the threat concerning the misuse of nuclear power, in a post-World War II-world. Thus we may see how translation, as a literary work of re-production, links the historical past with the recent past, and bridges two generations. As Willis Barnstone comments in The Poetics of Translation:

Translation, then, is the river. It carries us through time when it causes earlier moments and old literature to survive, when it floats some part of a tradition to us live and with recreated originality, then translation is art. (Barnstone, 1993, p. 30) 


\section{Conclusion}

In conclusion, one has to admit that the length and scope of Rāhā's translation, which was written chiefly for school-students, is too limited to exercise a fully "artistic mode of recreation". Yet, there are glimpses of the translator's originality; and though the translation is for children, there are suggestions and allusions which provoke further thoughts in the mind of the adult readers. This is where lies the "secret power" behind the Bengali translation of The Secret Power.

\section{References}

Barnstone, W. (1993). The poetics of translation: History, theory, practice. New Heaven and London: Yale University Press. Bassnett-Mcguire, S. (2002). Translation studies (3rd ed.). London and New York: Routledge.

Corelli, M. (1921). The secret power. Retrieved from http://www.gutenberg.org/files/3831/3831-h/3831-h.htm

Hallim, R. (2002). Marie Corelli: Science, society and the best seller. Retrieved from http://ses.library.usyd.edu.au/bitstream/2123/521/1/adt-NU20030623.11115901 front.pdf

Hollander, J. (1959). Visions, interpretations and performances. Cambridge: Harvard University Press.

Kālidāsa. (n.d). Kumāra-sambhavam in Sanskrita Sāhityasambhār (vol. II, 1978). Kolkātā: Nabapatra Prakāśan.

Mukhopādhyāy, V. (1978). Dvit ̄ ya Mahāyuddher Itihās (The history of the Second Great War). Kolkātā: Sākșaratā Prakāśan.

Rāhā, S. (1995). Kolkata, Deb Sāhitya Kuțīr (The secret power in Bengali). Kolkata: Deb Sāhitya Kuțir.

Steiner, G. (1975). After Babel: Aspects of language and translation. London: Oxford University Press.

The Book of Genesis, 18:23-14. (n.d). The King James Bible Online. Retrieved from http://www.kingjamesbibleonline.org/Genesis-Chapter-18/

The Book of Psalms, 3:5-6. (n.d). The King James Bible Online. Retrieved from http://www.kingjamesbibleonline.org/book.php?book=Psalms\&chapter=3\&verse $=5$ 